\title{
ZAKAT SEBAGAI SARANA PENGENTASAN KEMISKINAN (Studi Kasus di Lembaga Amil Zakat "Bina Umat Mandiri" Kabupaten Ngawi)
}

\author{
Hasti Ernawati \\ Fakultas Syari'ah UIN Maliki Malang
}

\begin{abstract}
Zakat as an institution, really closely with financial policy. Zakat even more important role compared with other social institutions such as orphanages and foundations in eliminating social inequality. This study aimed at understanding and management efforts Amil Zakat Institution "People Bina Mandiri" Ngawi district in order to alleviate poverty. Then once collected, the data is processed and analyzed with descriptive qualitative. The results showed, the Institute management Amil Zakat "People Bina Mandiri" Ngawi district is using an open system management (open management), namely income and spending zakat funds can be known directly by the public.

zakat memainkan peranan lebih penting dibanding dengan lembaga-lembaga sosial lainnya seperti panti asuhan dan yayasan-yayasan dalam menghapus kesenjangan sosial. Penelitian ini bertujuan memahami manajemen pengelolaan dan upaya yang dilakukan Lembaga Amil Zakat "Bina Umat Mandiri" Kabupaten Ngawi dalam rangka mengentaskan kemiskinan. Penelitian ini menggunakan penelitian kualitatif. Hasil penelitian menunjukkan, manajemen pengelolaan Lembaga Amil Zakat "Bina Umat Mandiri" Kabupaten Ngawi adalah menggunakan sistem open management (manajemen terbuka), yaitu pemasukan dan pengeluaran dana zakat dapat diketahui langsung oleh masyarakat.

Kata kunci: Zakat, Pengentasan Kemiskinan
\end{abstract}

Zakat adalah kewajiban yang tegas berdasarkan perintah Allah SWT dan bukan sekedar tanggung jawab yang dibebankan kepada seseorang. Zakat ditunaikan oleh mereka yang mengharapkan balasan Allah SWT di akhirat, dan terkadang ditinggalkan oleh mereka yang kurang yakin terhadap akhirat. Zakat bukan sekedar kemurahan seseorang kepada seseorang yang lain, melainkan suatu sistem tata sosial yang dikelola oleh negara melalui lembaga tersendiri. Lembaga ini mengatur semua mekanismenya, mulai dari pengumpulannya dari para wajib zakat dan pendistribusiannya kepada yang berhak. ${ }^{77}$

Zakat merupakan salah satu upaya yang digunakan untuk membina masyarakat muslim. Memberikan zakat merupakan salah satu alasan diberikannya wewenang kepada orang-orang yang berbuat baik untuk memakmurkan bumi. Zakat sebagai suatu lembaga, benar-benar lekat dengan kebijakan keuangan. Bahkan zakat memainkan peranan penting dalam menghapus kesenjangan sosial. Penerapannya tidak hanya dilakukan satu dua hari saja, melainkan melalui rentang waktu satu tahun. ${ }^{78}$

DiIndonesiapengelolaanzakatdiaturberdasarkan

\footnotetext{
77 Yusuf Qardhawi, Kiat Islam Mengentaskan Kemiskinan (Jakarta: Gema Insani Press, 1975), 106.

78 Yasin Ibrahim al- Syaikh, Zakat Menvempurnakan Puasa Membersihkan Harta (Bandung: Marja, 2004), 17.
}

UU No. 38 Tahun 1999 tentang pengelolaan zakat dengan keputusan Menteri Agama No. 581 Tahun 1999 dan Keputusan Jendral Bimbingan Masyarakat Islam dan Urusan Haji No. D/291 Tahun 2000 tentang pedoman teknis pengelolaan zakat. Meskipun harus diakui bahwa peraturan-peraturan tersebut masih banyak kekurangan yang sangat mendasar, misalnya tidak dijatuhkannya sanksi bagi para muzakki yang melalaikan kewajibannya (tidak mau berzakat) tetapi Undang-Undang No.38 tahun 1999 dikemukakan bahwa organisasi pengelolaan zakat terdiri dari dua jenis yaitu Lembaga Amil Zakat (LAZ) (pasal 7) dan Badan Amil Zakat (BAZ) (pasal 6). ${ }^{79}$

Apabila semuanya ini dapat dilaksanakan sebagaimana yang diatur dalam Undang-Undang, yaitu dengan diserahkannya zakat tersebut oleh muzakki kepada Lembaga Amil Zakat dan dikelola dengan baik sesuai dengan Undang-Undang, maka akan diperoleh suatu pengelolaan zakat yang efektif dan produktif.. LAZ yang baik yaitu lembaga yang mempunyai susunan organisasi yang memenuhi syarat, dengan adanya Dewan Pertimbangan, Komisi Pengawas, dan Badan Pelaksana. Selain itu, para personil dalam lembaga tersebut harus mempunyai tanggung jawab yang tinggi dan komitmen akan melaksanakan tu79 Didin Hafidhuddin, Zakat Dalam Perekonomian Modern (Yogyakaka : Gema Insani Press, 2003), 127. 
gasnya dengan sungguh-sungguh. Dan yang tidak kalah penting adalah sistem manajemen organisasi pengelolaan zakat yang baik, karena tidak ada artinya suatu Lembaga Amil Zakat bila sistem organisasinya amburadul dan tidak mempunyai suatu pedoman yang baik.

Lembaga Amil Zakat (LAZ) adalah institusi pengelola zakat yang sepenuhnya dibentuk atas prakarsa masyarakat yang bergerak dalam bidang dakwah, pendidikan, sosial dan kemaslahatan umat Islam. Adapun institusi yang mengurusi zakat yang lain adalah Badan Amil Zakat yaitu organisasi pengelola zakat yang di bentuk oleh pemerintah terdiri dari unsur masyarakat dan pemerintah dengan tugas mengumpulkan, mendistribusikan, dan mendayagunakan zakat sesuai dengan ketentuan agama. ${ }^{80}$

Lembaga Amil Zakat "Bina Umat Mandiri" di Kabupaten Ngawi merupakan salah satu sarana dan upaya untuk mewujudkan kesejahteraan masyarakat. Lembaga Amil Zakat ini mempunyai tugas pokok mengumpulkan, mendistribusikan, dan mendayagunakan zakat sesuai dengan ketentuan agama. Dengan adanya Lembaga Amil Zakat ini diharapkan mampu untuk mengurangi kemiskinan, karena dengan adanya kemiskinan akan menyebabkan berbagai permasalahan yaitu:

Pertama, kemiskinan akan membahayakan akidah, karena dalam kondisi yang seperti ini, kemiskinan dapat menebarkan benih keraguan terhadap kebijaksanaan Ilahi mengenai pembagian rezeki.

Kedua, kemiskinan akan membahayakan akhlak dan moral, karena kemelaratan dan kesengsaraan seseorang yang khususnya hidup dilingkungan golongan kaya yang tamak, sering mendorongnya melakukan tindak kriminal atau pelanggaran.

Ketiga, kemiskinan akan mengancam kestabilan pemikiran.

Keempat, kemiskinan membahayakan keluarga yang dapat menjadi ancaman, baik dalam segi pembentukan, kelangsungan, maupun keharmonisannya.

Kelima, kemiskinan mengancam masyarakat dan kestabilannya. ${ }^{81}$

Pada dasarnya, keberadaan Lembaga Amil Zakat "Bina Umat Mandiri" di Kabupaten Ngawi merupakan salah satu lembaga swasta yang bergerak dalam pengelolaan zakat, infaq, dan shadaqah, yang didirikan pada tahun 2001. Pada umumnya pengelo-

\footnotetext{
80 Keputusan Menteri Agama RI tentang Pelaksanaan UU No.38 Tahun 1999 tentang Pengelolaan Zakat Bab 1 Pasal 1 ayat 1 dan 2.

81 Yusuf Qardhawi, Kiat Islam Mengentaskan Kemiskinan (Jakarta: Gema Insani Press, 1975) 24-29.
}

laan zakat di Kabupaten Ngawi ditangani oleh Badan Amil Zakat milik pemerintah dan beberapa organisasi lainnya seperti panitia zakat Nahdhatul Ulama dan panitia zakat Muhammadiyah. Dengan demikian masing-masing organisasi mendirikan kepanitiaan yang menggunakan sistem pengelolaan menerima zakat yang diperoleh dari masyarakat kemudian disalurkan kembali kepada masyarakat, sesuai dengan ketentuan syariat.

Lembaga Amil Zakat "Bina Umat Mandiri" yang ada di Kabupaten Ngawi adalah lembaga sosial yang merupakan lembaga alternatif yang berasaskan Islam. Berfungsi untuk meningkatkan pemerataan kesejahteraan kehidupan umat Islam. Di mana Lembaga Amil Zakat "Bina Umat Mandiri" yang nantinya akan mengarah kepada apa yang disebut fungsi lembaga sosial secara umum. Namun untuk saat ini Lembaga Amil Zakat "Bina Umat Mandiri” di Kabupaten Ngawi hanya memulai aktivitasnya pada pengumpulan dan pendistribusian zakat saja.

Adapun orang-orang yang menjadi pengurus Yayasan Harum berinisiatif untuk mendirikan Lembaga Amil Zakat "Bina Umat Mandiri". Mereka terdiri dari : H. Riyadh Rosyadi, Drs. Sudirman, Tri Kusdiarto, Maryoto, S. Pd, Ir. Yahya Amin, MP, Joko Pitoyo, SE. Ak. Perkembangan selanjutnya pada tanggal $13 \mathrm{Ja}-$ nuari 2001 lembaga ini dilegalkan di depan notaris Muchammad Ikhwanul Muslimin, SH dengan Akta No. 5 Kabupaten Ngawi.

Berdasarkan keadaan tersebut, maka peneliti akan melihat secara langsung manajemen zakat yang dikelola oleh Lembaga Amil Zakat "Bina Umat Mandiri” di Kabupaten Ngawi. Hal ini karena peneliti memandang peran zakat sangatlah penting sebagai salah satu sarana pengentasan kemiskinan, akan tetapi semua itu tidak terlepas bagaimana orang-orang yang akan mengelolanya sehingga dalam pengelolaan itu mampu untuk mewujudkan masyarakat yang sejahtera.

\section{METODE}

Penelitian ini menggunakan pendekatan kualitatif. Data yang tidak berbentuk angka atau tidak dapat diangkakan, karena dalam menganalisis data digunakan kata-kata bukan angka. Bertujuan untuk memahami makna fenomena-fenomena yang terjadi di dalam Lembaga Amil Zakat "Bina Umat Mandiri” Kabupaten Ngawi. Pendekatan kualitatif ini digunakan karena beberapa pertimbangan; pertama, menyesuaikan pendekatan kualitatif lebih mudah apabila berhadapan dengan kenyataan ganda; kedua, pendekatan ini menvaiikan secara langsung 
hakikat hubungan antara peneliti dan informan; ketiga, pendekatan ini lebih peka dan lebih dapat menyesuaikan diri dengan banyak penajaman pengaruh bersama dan terhadap pola-pola nilai yang dihadapi.

Data yang diperoleh dari lapangan maupun dokumentasi kemudian diolah dan diproses. Untuk mendapatkan hasil yang sesuai dengan pembahasan, maka penelitian ini menggunakan teknik sebagai berikut:

Tahap pertama adalah editing, yaitu pemeriksaan kembali semua data yang diperoleh terutama dari kelengkapannya, kejelasan makna, kesesuaian serta relevansi dengan pokok permasalahan. ${ }^{82}$ Tahap ini dilakukan untuk mengecek keterwakilan kelengkapan para informan. Tahap selanjutnya adalah classifying, maksudnya adalah untuk menjadikan pembacaan penelitian lebih mudah karena telah dikelompokkan dalam beberapa kategori. Adapun tahap akhir adalah analysing sebagai tahap yang paling penting karena disinilah letak yang signifikan dari penelitian ini. Apapun yang didapat akan menjadi rekomendasi dari Lembaga Amil Zakat apakah sudah sesuai dengan visi, misi dan tujuan adanya Lembaga Amil Zakat "Bina Umat Mandiri". Peneliti melakukan analisis data secara deskriptif kualitatif yaitu analisis yang menggambarkan keadaan atau status fenomena dengan kata-kata atau kalimat kemudian dipisahkan menurut kategori untuk memperoleh kesimpulan. ${ }^{83}$

\section{HASIL DAN PEMBAHASAN}

LAZ Bina Umat Mandiri memiliki struktur organisasi inti yang terdiri dari ketua, sekretaris dan bendahara. Di samping itu, LAZ Bina Umat Mandiri juga memiliki divisi penghimpunan dana dan pendistribusian. Adapun tugasnya secara rinci yaitu :

Ketua, tugasnya sebagai pemimpin dalam pelaksanaan, mengatur dengan segenap kemampuannya agar pelaksanaan Lembaga Amil Zakat dapat berjalan dengan sebaik-baiknya sesuai dengan harapan. Sekretaris, tugasnya adalah mengadakan pembukuan keadministrasian mulai dari awal proses pengumpulan zakat sampai dengan penyaluran kepada yang berhak menerimanya, dan pelaporan tugas kerja utamanya menyelesaikan segala hal yang ada kaitannya dengan kegiatan keadministrasian Lembaga Amil Zakat "Bina Umat Mandiri" untuk memudahkan pengendalian agar terhindar dari adanya pelaksanaan yang kurang dapat dipertanggung jawabkan. Sedangkan bendahara, tugasnya menerima

82 Marzuki. Metodologi Rizet (Yogyakarta: BP-FE-UI, 1997), 81.

83 Suharsimi Arikunto, Prosedur Penelitian Suatu Pendekatan Praktek (Jakarta: Rineka Cipta, 2002), 245 dari hasil pengumpulan zakat yang berupa uang atau beras dan menjaga barang hak milik Lembaga Amil Zakat yang telah terkumpulkan.

Adapun Divisi Penghimpunan Dana, tugasnya mengumpulkan hasil dari zakat yang berupa uang dan beras yang disetorkan pada tempat-tempat yang telah di tentukan. Setelah zakat terkumpul, maka selanjutnya zakat didistribusikan kepada yang berhak menerimanya oleh Divisi Pendistribusian. Kemudian upaya-upaya yang dilakukan Lembaga Amil Zakat "Bina Umat Mandiri" Kabupaten Ngawi dalam rangka pengentasan kemiskinan, antara lain :

Pertama, Beasiswa, Program yang dia-dakan "BINUMA" dalam bentuk beasiswa ini ada dua jenis yaitu: Beasiswa Anak Yatim, diantaranya anak yatim tidak mampu dan anak yatim rawan putus sekolah. Sedangkan Beasiswa dhu'afa dan yatim, terdiri dari anak orang tidak mampu, anak rawan putus sekolah dan anak yang rawan pendangkalan aqidah.

\section{Tabel I}

Beasiswa untuk anak yatim di periode 30 Juni-November 2007

\begin{tabular}{|c|c|c|c|}
\hline NO & NAMA & ALAMAT & SEKOLAH \\
\hline 1. & Supriyadi & $\begin{array}{l}\text { Dsn. Kiyonten, Ds. Kiyonten, } \\
\text { Kec. Kasreman }\end{array}$ & SDN Lego Kulon \\
\hline 2. & Chorul Azis & $\begin{array}{l}\text { Dsn. Ngablak RT } 06 / \text { RW } 02 . \\
\text { Ds. Pacing, Kec. Padas }\end{array}$ & SMPN 1 Padas \\
\hline 3. & Muhammad F & $\begin{array}{l}\text { Dsn, Ngablak RT 02/RW 02, } \\
\text { Ds. Pacing, Kec. Padas }\end{array}$ & SMPN 1 Padas \\
\hline 4. & Arya Dwi P & $\begin{array}{l}\text { Dsn. Banjar, Ds. Ngawi, Kec. } \\
\text { Ngawi }\end{array}$ & SMPN 1 Ngawi \\
\hline 5. & Astutik & $\begin{array}{l}\text { Dsn. Dungus, Ds, Karangsari, } \\
\text { Kec. Ngawi }\end{array}$ & SMPN 5 Ngawi \\
\hline 6. & $\begin{array}{l}\text { Ayunda } \\
\text { Prima S }\end{array}$ & $\begin{array}{l}\text { Margomulyo RT 05/RW 01, } \\
\text { Ds. Margomulyo, Ngawi }\end{array}$ & $\begin{array}{l}\text { SDN Karang } \\
\text { Tengah } 5\end{array}$ \\
\hline 7. & Sri Lestari & $\begin{array}{l}\text { Margomulyo RT 05/RW 01, } \\
\text { Ds. Margomulyo, Ngawi }\end{array}$ & SMPN 1 Ngawi \\
\hline 8. & $\begin{array}{l}\text { Husa'in } \\
\text { Abdullah }\end{array}$ & $\begin{array}{l}\text { Dsn. Pojok RT 05/RW 01, Ds. } \\
\text { Beran, Kec. Ngawi }\end{array}$ & MTsN Ngawi \\
\hline 9. & Suroto & $\begin{array}{l}\text { Dsn. Blandongan RT 01/RW } \\
\text { 01, Ds. Ngawi, Kec. Ngawi }\end{array}$ & MTsN Ngawi \\
\hline 10. & $\begin{array}{l}\text { Choirul Al- } \\
\text { Fizahri }\end{array}$ & Ds. Pleset, Kec. Pangkur & SMPN 1 Pangkur \\
\hline 11. & Arif Sutanto & $\begin{array}{l}\text { Dsn. CangakanI Ds. } \\
\text { Cangakan, Kec. Kasreman }\end{array}$ & $\begin{array}{l}\text { SMPN 1 } \\
\text { Kasreman }\end{array}$ \\
\hline 12. & Imam Muslimin & $\begin{array}{l}\text { Ds. Cangakan Dsn. Cangakan } \\
1 \text { Kec. Kasreman }\end{array}$ & $\begin{array}{l}\text { SMPN 1 } \\
\text { Kasreman }\end{array}$ \\
\hline 13. & $\begin{array}{l}\text { Aris Novi } \\
\text { Biwayanti }\end{array}$ & $\begin{array}{l}\text { Ds. Sumengko Kec. } \\
\text { Kwadungan }\end{array}$ & $\begin{array}{l}\text { SMSN 1 } \\
\text { Kwadungan }\end{array}$ \\
\hline 14. & $\begin{array}{l}\text { Umirul } \\
\text { Chasanah }\end{array}$ & Kawu Trinil Kec. Kedunggalar & MAN Ngawi \\
\hline
\end{tabular}

Dari data-data yang telah dipaparkan diatas, maka menurut pendapat peneliti program tersebut mempunyai peran dan pengaruh yang lebih besar dibandingkan dengan yang lain dalam rangka mengentaskan kemiskinan yang ada di Kabupaten Ngawi. Karena program ini begitu meyakinkan untuk menjadidinnestasihjangka panjang atau lebih bersifat

\section{(n) nitro $^{\text {PDF }^{\prime}}$ professional}


produktif bukan bersifat konsumtif. Dari program ini diharapkan para siswa mampu mengenyam pendidikan secara layak, tidak mendapatkan kendala-kendala yang berarti. Para siswa mampu melanjutkan jenjang pendidikannya ke jenjang yang lebih tinggi lagi. Yang pada akhirnya mereka mampu mencetuskan pemikiran untuk mengubah kondisi perekonomian mereka. Tidak menjadi beban bagi dalam masyarakat, akan tetapi justru berubah menjadi orang yang mampu membantu masyarakat lain yang kurang mampu.

Memang dalam mewujudkan sebuah tujuan tidak bisa diwujudkan dalam waktu yang sangat singkat. Butuh waktu yang cukup lama untuk mewujudkannya. Apalagi ini untuk mewujudkan sesuatu yang besar, mewujudkan masyarakat yang bebas dari kondisi kemiskinan. Ini juga tidak terlepas dari sistem dilingkungan sekitar, yang secara otomatis sangat berpengaruh besar terhadap kinerja di sebuah Lembaga Amil Zakat.

Adapun hasil wawancara dengan ketua lembaga amil zakat, beliau mengutarakan bahwa selama ini LAZ belum dapat mengentaskan mereka dari situasi kemiskinan. Jadi program-program yang ada masih mengupayakan untuk menuju ke arah sana, yakni pengentasan kemiskinan. Indikator seseorang dikatakan miskin yaitu apabila pengeluarannya lebih besar dari pendapatannya. Maksudnya, seseorang dalam mencukupi kebutuhan hidupnya itu belum bisa terpenuhi secara layak.

Kedua, Kafalah Du'at, Wawancara dengan Bapak Atok Sunu, sebagai ketua Lembaga Amil Zakat "Bina Umat Mandiri" menyatakan bahwa di Lembaga Amil Zakat "Bina Umat Mandiri" juga memberikan bantuan kepada para Da'i dalam bentuk transportasi untuk pergi ketempat mereka akan berdakwah. Adapun daerah-daerah yang diprioritaskan oleh para Da'i ialah daerah terpencil yang sekiranya kehadiran para Da'i tersebut sangat dibutuhkan, seperti di Kecamatan Bringin dan Kecamatan Pitu.

Kemudian diberikan juga bantuan untuk keperluan sehari-hari sebagai penunjang kebutuhannya. Hal ini diberikan kepada para Da'i yang dalam perekonomiannya belum mapan sehingga proses dakwahpun tetap berjalan dengan lancar dan bantuan ini diberikan disetiap bulan. Pada laporan pengeluaran Lembaga Amil Zakat "Binuma" bulan November 2007 memberikan bantuannya sebesar Rp 500.000,Pemberian bantuan ini seyogyanya menjadi langkah motivasi internal dan eksternal.

Motivasi internal sebagai pemberi semangat bahwa niat dan langkah mereka berjuang dan menga- jar menjadi perhatian bersama umat Islam. Motivasi eksternal mengarahkan masyarakat untuk diperhatikan kesejahteraan para Da'i dan para guru TPA yang selama ini tidak terlalu penting untuk diperhatikan. Tidak dilupakan juga bantuan pemberian dana pada anak-anak mereka untuk tetap bisa duduk di bangku sekolahan. Hal ini tetap bisa berjalan seiring sejalan, dakwah tetap berjalan dan anak-anak merekapun tetap mendapatkan pendidikan yang layak.

Ketiga, Waqaf Al-Qur'an dan Iqra', Program lain dari lembaga amil zakat ini adalah berupa waqaf al-Qur'an dan iqra' yang diberikan ke masjid, mushalla dan taman pendidikan Quran. Ini diharapkan masyarakat bisa untuk membumikan ayat-ayat Allah di muka bumi. Masyarakat lebih bisa mencintai Allah dan RasulNya daripada dunia dan seisinya.

Keempat, Bantuan Pendidikan TPA dan TKIT, Untuk bantuan ini, Lembaga Amil Zakat "Bina Umat Mandiri" menyerahkan bantuan pendidikan TKIT (Taman Kanak-kanak Islam Terpadu) Harapan Ummat Kabupaten Ngawi di jalan S. Parman gang Soka No. 24 Ngawi pada bulan Agustus 2007 berupa monitor komputer. Dimaksudkan supaya dengan adanya fasilitas ini proses dalam pendidikan bisa berjalan dengan lebih baik.

Selain membantu dalam segi pendidikan, Lembaga Amil Zakat juga membantu untuk merenovasi gedung dengan memberikan bantuan berupa materiil dan logistik. Dalam bentuk materiil ini misalkan berupa bentuk semen atau dengan uang tunai. Sedangkan bantuan yang berupa logistik berupa Al-Qur'an dan buku-buku keagamaan lainnya.

Kelima, Bantuan Renovasi Masjid/mushalla, Bantuan ini diberikan ke masjid atau mushalla yang membutuhkan. Seperti yang disampaikan oleh bapak Atok Sunu, beliau mengatakan bahwa LAZ ini juga memberikan bantuan untuk merenovasi masjid, tetapi belum bisa membangun masjid yang besar, hanya bisa membantu setara dengan 10 sak semen atau dalam bentuk uang $\mathrm{Rp} 400.000,00$.

\section{Tabel II}

Adapun masjid atau mushalla yang mendapatkan bantuan antara lain terdapat pada tabel berikut:

\begin{tabular}{|c|l|l|c|c|}
\hline NO & \multicolumn{1}{|c|}{$\begin{array}{c}\text { JENIS } \\
\text { PENYALURAN }\end{array}$} & TEMPAT & $\begin{array}{l}\text { BULAN/ } \\
\text { TAHUN }\end{array}$ & JUMLAH \\
\hline 1. & $\begin{array}{l}\text { Bantuan Mushalla } \\
\text { Baitul Iman }\end{array}$ & $\begin{array}{l}\text { Dsn. } \\
\text { Sidomulyo, Ds. } \\
\text { Kandangan }\end{array}$ & $09 / 2007$ & $300.000,-$ \\
\hline 2. & $\begin{array}{l}\text { Bantuan } \\
\text { Mushallanya Pak Pur }\end{array}$ & Geneng & $09 / 2007$ & $300.000,-$ \\
\hline 3. & $\begin{array}{l}\text { Bantuan Masjid } \\
\text { Hidayatullah }\end{array}$ & $\begin{array}{l}\text { Dsn. Suko, Ds. } \\
\text { Karangasri }\end{array}$ & $09 / 2007$ & $216.000,-$ \\
\hline
\end{tabular}




\begin{tabular}{|c|l|l|c|c|}
\hline 4. & $\begin{array}{l}\text { Bantuan Masjid } \\
\text { Baitussalam }\end{array}$ & $\begin{array}{l}\text { Ds. } \\
\text { Karangsono, } \\
\text { Kec. } \\
\text { Kwadungan }\end{array}$ & $11 / 2007$ & $300.000,-$ \\
\hline 5. & $\begin{array}{l}\text { Bantuan Masjid } \\
\text { Baitul Hikmah }\end{array}$ & $\begin{array}{l}\text { Ds. } \\
\text { Karangtengah, } \\
\text { Prandon }\end{array}$ & $11 / 2007$ & $400.000,-$ \\
\hline
\end{tabular}

Dengan bantuan ini diharapkan maqsjid atau mushalla bisa cepat selesai dan bisa dimanfaatkan masyarakat untuk shalat berjamaah dan untuk kegiatan keagamaan yang lain, yang bisa untuk menunjang pengokohan aqidah masyarakat.

Keenam, Bantuan Daerah Bencana, Pelaksanaan bantuan ini diberikan ke Desa Sumber Bening Kecamatan Bringin yang terkena musibah diterjang angin puting beliung pada tanggal 24 Oktober 2007 kemarin. Oleh sebab itulah dari pihak Lembaga Amil Zakat "Bina Umat Mandiri" memberikan bantuan berupa uang tunai kepada keluarga yang ditimpa musibah, khususnya mereka yang rumahnya roboh total dan sangat membutuhkan bantuan untuk perbaikan rumah mereka. Bantuan pertama diserahkan ke Bapak Wito yang rumahnya hancur total, beliau memiliki satu orang anak dan bekerja sebagai petani. Kemudian selanjutnya diserahkan ke Ibu Saini yang sehari-harinya juga bekerja sebagai petani, kemudian diberikan juga kepada seorang nenek yang hidup bersama cucunya. Semuanya ini dilakukan dalam rangka meringankan beban yang ada di pundak mereka. Dan menurut bapak Atok Sunu Prastowo, pengalokasian dana pada daerah bencana ini bertujuan agar mereka tidak terjebak dengan hutang. Hal ini disebabkan karena kondisi ekonomi dalam masyarakat semakin memburuk, dengan keadaan itu dikhawatirkan ada oknum-oknum tertentu untuk mengambil keuntungan pribadi. Program ini dilakukan hanya bersifat insidental, hanya sewaktu-waktu ketika ada musibah menimpa masyarakat ngawi.

Ketujuh, Daurah Pembinaan Umat, Di Lembaga Amil Zakat ini juga ada program daurah pembinaan umat atau biasa disebut dengan training tsaqofah. Training ini contohnya di Kecamatan Pitu dengan tema "Kantin Gaul 57" (Kajian Rutin Generasi Unggul) se-Kecamatan Pitu" nama trainning yang diadakan ini bekerjasama dengan karang taruna "Budi Karya" Watugudel Pitu. Diadakan setiap bulan pada hari Ahad minggu keempat, yang dihadiri oleh para pemuda dan pemudi se-Kecamatan Pitu baik dari wakil remas, pelajar, karang taruna dan lain-lain, dengan materi-materi baik agama dan pengetahuan lain. Program ini diharapkan dapat mencetak pemuda- pemudi yang Gaul "Generasi Ung- gul”. Maksudnya menjadikan mereka cepat tanggap terhadap permasalahan yang ada di tengah-tengah masyarakat, serta mengetahui bagaimana menyelesaikan permasalahan tersebut dengan solusi yang tepat. Jadi program ini juga bertujuan untuk mencerdaskan umat agar tidak terkungkung didalam kebodohan. Karena kebodohan itu salah satu penyebab terjadinya kemiskinan. Karena seorang yang fakir pada umumnya tidak bisa belajar ataupun mengajarkan dan menyekolahkan anak-anak mereka, karena itulah pendidikan merupakan urgensitas yang harus dipenuhi oleh kaum fakir pada masa ini, dengan mendayagunakan zakat yang ada untuk belajar dan menyekolahkan anak-anak mereka demi kepentingan duniawi dan ukhrawi. ${ }^{84}$

Kedelapan, Penyaluran zakat fitrah, Zakat fitrah ini dibagikan kepada orang-orang yang tidak mampu di daerah-daerah yang telah ditentukan dan yang ada di sekitarnya. Baik yang berwujud uang maupun beras. Zakat fitrah ini tidak hanya berasal dari masyarakat sekitar, akan tetapi juga berasal dari lembaga-lembaga yang berada di Kabupaten Ngawi. Dalam penyalurannya yang lebih diutamakan ialah orang-orang terdekat, kemudian dilanjutkan orangorang yang agak jauh dari kantor zakat.

Sesungguhnya zakat juga dapat diistilahkan sebagai jaminan sosial yakni jaminan sosial bagi masyarakat yang membutuhkan, orang-orang yang tidak mampu untuk bekerja, orang tua yang sudah jompo, tentu mereka berhak untuk mendapatkan dana dari zakat. Dan status mereka dapat disebut sebagai orang yang fakir atau bisa juga disebut sebagai orang yang miskin. Dana zakat yang diberikan kepada mereka bertujuan untuk dapat digunakan dalam memenuhi kebutuhan sehari-harinya karena mereka tidak mampu untuk bekerja. ${ }^{85}$

Akan tetapi bantuan ini tidak bisa dijadikan sebagai jaminan bahwa kemiskinan tersebut dapat dientaskan, karena bantuan ini hanya bersifat konsumtif saja. Bantuan ini hanya bisa untuk memenuhi mereka yang membutuhkan kebutuhan sehari-hari dan hanya berguna untuk sekali pakai saja. Tidak bisa dijadikan sebagai investasi jangka panjang.

Kesembilan, Penyaluran ke 'Amil Zakat, Amil zakat adalah mereka yang melaksanakan segala kegiatan yang berkaitan dengan urusan zakat, mulai dari proses penghimpunan, penjagaan, pemeliharaan,

84 YusufQaradhawi, Spektrum Zakat Dalam Membangun Ekonomi Kemasyarakatan (Jakarta : Zikrul 1987). 50

85 Didifr ratadihwiddin, Agar Harta Berkah dan Bertam- 
sampailah proses pendistribusiannya, serta tugas pencatatan masuk dan keluarnya dana zakat tersebut. Para pengurus badan atau lembaga zakat berhak mendapat bagian zakat dari bagian amil atas kerja mereka yang diberikan oleh pihak yang mengangkat mereka dengan catatan bagian tersebut tidak melebihi dari upaya standar. ${ }^{86}$

Pada masa Rasulullah SAW, yang diangkat menjadi amil zakat adalah Sayyidina Umar Bin Khattab ra. Ketika Umar menjadi khalifah, beliau mengangkat Ibnus Sa'dy Al-Maliki sebagai pengumpul zakat. Dalam hadits Rasulullah SAW :

Dari Ibnu As-Saidi, dia berkata, "Umar bin Khaththab RA menjadikan aku sebagai amil yang mengumpulkan shadaqah (zakat), maka ketika aku menyelesaikan pekerjaan itu dan menyampaikan kepadanya, ia memerintahkan untuk memberikan kepadaku upah," maka aku berkata, "Aku mengerjakannya hanya karena Allah, dan ganjaranku hanya dari Allah," dia berkata, "Ambillah apa yang aku berikan kepadamu, karena sesungguhnya aku telah mengerjakan pekerjaan ini pada zaman Rasulullah SAW, dan beliau memberi kepadaku upah (waktu itu) aku mengatakan seperti apa yang kamu katakan, Rasulullah SAW bersabda, "Apabila kamu di berikan sesuatu tanpa kamu memintanya, maka makanlah dan sedekahkanlah." (Shahih, Muttafaq Alaih). ${ }^{87}$

Berdasarkan keterangan dari Bapak Atok Sunu, penyaluran untuk 'Amil ini terbagi menjadi dua yaitu: a) Amil yang meliputi kader-kader dari lembaga Amil Zakat "Bina Umat Mandiri" sebagai pengurus dari lembaga tersebut. b) Amil yang diartikan lembaga itu sendiri. Bagian untuk amil ditetapkan sebesar 1/8 setara dengan 12,5\% pendapat Imam Syafi'i.

Metode Pengelolaan Zakat di Lembaga Amil Zakat "Bina Umat Mandiri” Kabupaten Ngawi dibedakan menjadi tiga macam, antara lain:

Pengumpulan Zakat pada Lembaga Amil Zakat "Bina Umat Mandiri" Kabupaten Ngawi

Dalam pengumpulan zakatnya yang pertama kali ditempuh oleh pengurus Lembaga Amil Zakat adalah: a) Menyebar-kan informasi tentang keberadaan Lembaga Amil Zakat melalui brosur ataupun media cetak seperti majalah tiga bulanan yang ditertibkan oleh Lembaga Amil Zakat tersebut. b) Kegiatan pengumpulan zakat biasanya dengan memanfaatkan momentum Bulan Ramadhan. c) Pengumpulkan zakat tidak hanya dari masyarakat saja, akan teapi juga dari kader Lembaga Amil Zakat

86 Ibid, 179

87 Muhammad Nashiruddin Al-Albani, Shahih Sunan

Abu Daud (Jakarta : Pustaka Azzam, 2007). 640. dan menjalin kerjasama dengan yayasan "Harum" (Harapan Umat), yaitu yayasan yang bergerak dalam bidang pendidikan, setaraf dengan TK, TPA yang ada di Kabupaten Ngawi.. Kerjasama tersebut terbentuk karena sebagian besar pengurus Lembaga Amil Zakat merupakan pengurus yayasan "Harum". Selain itu Lembaga Amil Zakat juga bekerjasama dengan lembaga pendidikan seperti MAN Paron, SMK PGRI, SMA 2, SMA 1, juga lembaga milik pemerintah, meliputi BRI dan PDAM. Dalam hal ini Lembaga Amil Zakat memberikan penawaran pada lembaga-lembaga tersebut untuk membantu dan mendistribusikan zakatnya. Jika lembaga tersebut setuju, maka pada bulan ramadhan, zakat fitrah yang terkumpul akan diserahkan pada Lembaga Amil Zakat dan selanjutnya akan disalurkan pada para mustahiq zakat.

Pengelolaan Dana Zakat pada Lembaga Amil Zakat "Bina Umat Mandiri" Kabupaten Ngawi

Dalam pengelolaan dana zakatnya, Lembaga Amil Zakat "Bina Umat Mandiri" menerapkan open management atau managemen keterbukaan. Bapak Atok mengungkapkan bahwa Lembaga Amil Zakat ini terbuka untuk umum yang diharapkan masyarakat mengetahui bagaimana kinerja lembaga zakat ini, keluar dan masuknya dana bisa tersalurkan dengan jelas, dan tidak ilegal. Jadi kapanpun lembaga ini siap untuk mempertanggungjawabkan kepada masyarakat.

Akan tetapi terkait dengan managemen zakat nampaknya belum banyak diperhatikan orang. Zakat masih dianggap persoalan ringan yang tidak perlu dikelola secara profesional. Apalagi ketika disebut zakat, orang segera mempersepsikan zakat fitrah dalam benaknya dan zakat fitrah cukup dilaksanakan di akhir bulan ramadhan. Dengan demikian, manajemen zakat tidak diperlukan dalam pengelolaan zakat. ${ }^{88}$ Untuk memaksimalkan pengelolaan dana zakatnya, Lembaga Amil Zakat "Bina Umat Mandiri" membagi prosentase dana zakat menjadi dua yaitu : a. $60 \%$ untuk mustahiq. b. $40 \%$ dari dana wakaf, infak dan shadaqoh.

\section{Penyaluran Zakat pada Lembaga Amil Zakat "Bina Umat Mandiri” Kabupaten Ngawi}

Dalam penyaluran zakat, para amil di Lembaga Amil Zakat "Bina Umat Mandiri” mengacu pada firman Allah dalam surat at-Taubah ayat 60 , intinya dari ayat tersebut bahwa penyaluran zakat diberikan kepada delapan asnaf. Adapun dalam memberikan kepada delapan asnaf tersebut berbeda-beda sesuai

8 Sudirnfahtectakt Dalam Pusaran Arus Modernitas

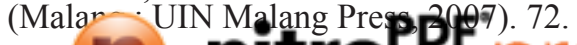


dengan kebutuhan, dengan kata lain meskipun semuanya mendapatkan tapi yang lebih diprioritaskan adalah orang-orang yang mempunyai kepentingan mendesak.

\section{Analisis Pemasukan dan Pengeluaran Zakat di Lembaga Amil Zakat "Bina Umat Mandiri" Kabupaten Ngawi}

Dalam bagian pembahasan ini, peneliti berusaha menganalisis hasil dari pengelolaan zakat dilihat dari pemasukan dan pengeluaran zakat apakah sudah tersalurkan dengan baik dan mampu untuk mengentaskan kemiskinan atau belum. Di sini peneliti mencantumkan data-data penerimaan dan pengeluaran zakat dari tahun 2004-2007 sebagai upaya untuk menguatkan hasil dari penelitian tersebut. Yang kemudian setelah dianalisis peneliti mampu untuk memberikan kesimpulan dari apa yang telah di temukan.

\section{Tabel III}

Pemasukan dan Pengeluaran Zakat di Lembaga Amil Zakat

"Bina Umat Mandiri" Kabupaten Ngawi di Tahun 2004-2005

\begin{tabular}{|c|c|c|c|c|}
\hline NO & PEMASUKAN & JUMLAH & PENGELUARAN & JUMLAH \\
\hline 1. & Zakat Fitrah & 4.512 .000 & $\begin{array}{l}\text { Penyaluran Zakat } \\
\text { Fitrah }\end{array}$ & 4.512 .000 \\
\hline 2. & Fidyah & 1.291 .000 & Bantuan Daerah & 2.850 .000 \\
\hline 3. & Zakat Maal & 28.070 .500 & $\begin{array}{l}\text { Bencana } \\
\text { Bantuan Renovasi } \\
\text { TPA dan TKIT }\end{array}$ & 7.500 .000 \\
\hline 4. & Zakat Profesi & 5.343 .100 & $\begin{array}{l}\text { Bantuan Renovasi } \\
\text { Masjid/Mushalla }\end{array}$ & 2.095 .000 \\
\hline 5. & $\begin{array}{l}\text { Infak dan } \\
\text { Shadaqah }\end{array}$ & 2.833 .500 & $\begin{array}{l}\text { Bantuan } \\
\text { Pengobatan } \\
\text { Keluarga Da'i }\end{array}$ & 500.000 \\
\hline 6. & Lain-lain & 43.500 & Kafalah Dakwah & 6.184 .900 \\
\hline 7. & & & $\begin{array}{l}\text { Santunan Anak } \\
\text { Yatim dan Fakir } \\
\text { Miskin }\end{array}$ & 6.910 .000 \\
\hline 8. & & & $\begin{array}{l}\text { Penyaluran ke } \\
\text { Amil Zakat }\end{array}$ & 6.309 .200 \\
\hline 9. & & & $\begin{array}{l}\text { Bantuan Daerah } \\
\text { Tertinggal }\end{array}$ & 2.901 .000 \\
\hline 10. & & & $\begin{array}{l}\text { Dana Operasional } \\
\text { th. 2004-2005 }\end{array}$ & 1.054 .000 \\
\hline & $\begin{array}{l}\text { Total } \\
\text { Pemasukan }\end{array}$ & 41.893 .600 & Total Pengeluaran & 40.816 .100 \\
\hline
\end{tabular}

\section{Tabel IV}

Pemasukan dan Pengeluaran Zakat di Lembaga Amil Zakat

"Bina Umat Mandiri" Kabupaten Ngawi Tahun 2005-2006

\begin{tabular}{|c|l|l|l|l|}
\hline NO & PEMASUKAN & JUMLAH & PENGELUARAN & JUMLAH \\
\hline 1. & Zakat Fitrah & 7.575 .000 & $\begin{array}{l}\text { Penyaluran Zakat } \\
\text { Fitrah }\end{array}$ & 7.575 .000 \\
\hline 2. & Fidyah & 235.000 & Penyaluran Fidyah & 235.000 \\
\hline 3. & Zakat Maal & 55.845 .000 & $\begin{array}{l}\text { Santunan Anak } \\
\text { Yatim }\end{array}$ & 6.000 .000 \\
\hline 4. & Zakat Profesi & 1.870 .000 & Fi Sabilillah & 3.500 .000 \\
\hline 5. & Infak/Shadaqah & 5.670 .000 & Ghorimin & 1.000 .000 \\
\hline 6. & Infak Yatim & 400.000 & Fakir Miskin & 5.000 .000 \\
\hline 7. & Lain-lain & 521.000 & $\begin{array}{l}\text { Alokasi untuk } \\
\text { Amilin }(2,5 \% \text { dari } \\
\text { penerimaan zakat) }\end{array}$ & 1.396 .125 \\
\hline
\end{tabular}

\begin{tabular}{|c|l|l|l|l|}
\hline 8. & & & $\begin{array}{l}\text { Santunan } \\
\text { Pengobatan }\end{array}$ & 250.000 \\
\hline 9. & & & $\begin{array}{l}\text { Bantuan Modal } \\
\text { untuk Mustahiq }\end{array}$ & 2.000 .000 \\
\hline 10. & & $\begin{array}{l}\text { Bantuan } \\
\text { Pembangunan } \\
\text { Masjid Derah } \\
\text { Tertinggal }\end{array}$ & 1.500 .000 \\
\hline 11. & & & $\begin{array}{l}\text { Kafalah Ustadz/ } \\
\text { Ustadzh }\end{array}$ & 1.250 .000 \\
\hline 12. & & & Operasional & 1.250 .000 \\
\hline 13. & & $\begin{array}{l}\text { Alokasi Ke } \\
\text { Lembaga Dakwah } \\
\text { Binaan }\end{array}$ & 500.000 \\
\hline & $\begin{array}{l}\text { Total } \\
\text { Pemasukan }\end{array}$ & $\mathbf{7 2 . 1 1 6 . 0 0 0}$ & Total Pengeluaran & $\mathbf{3 1 . 4 5 6 . 1 2 5}$ \\
\hline
\end{tabular}

Tabel V

Penerimaan dan Pengelaran Zakat di Lembaga Amil Zakat

"Bina Umat Mandiri” Kabupaten Ngawi Tahun 2007

\begin{tabular}{|c|c|c|c|c|c|c|}
\hline NO & BULAN & ALOKAST & DEBET & KREDIT & SALDO & JUMLAH \\
\hline \multirow[t]{4}{*}{1.} & Maret & Infak & 562.000 & 166.000 & 396.000 & \\
\hline & & SAY & 45.000 & & 45.000 & \\
\hline & & Zakat & 650.000 & & 650.000 & \\
\hline & & Jumlah & 1.662 .000 & 1.662 .000 & 1.496 .000 & \\
\hline \multirow[t]{4}{*}{2.} & April & Infak & 427.000 & 106.700 & 320.300 & 14.996 .000 \\
\hline & & SAY & 390.000 & 210.100 & 179.900 & \\
\hline & & Zakat & 590.000 & 187.320 & 402.680 & \\
\hline & & Jumlah & 1.407 .000 & 504.120 & 902.880 & 902.880 \\
\hline \multirow[t]{4}{*}{3.} & Mei & Tnfak & 2.242 .000 & 61.600 & 2.180 .400 & \\
\hline & & SAY & 835.000 & 354.800 & 480.200 & \\
\hline & & Zakat & 240000 & 65.300 & 174.700 & \\
\hline & & Jumlah & 3.317 .000 & 481.700 & 2.835 .300 & 2.835 .300 \\
\hline \multirow[t]{4}{*}{4.} & Juni & Infak & 1.375 .000 & 1.065 .480 & 309.520 & \\
\hline & & SAY & 420.000 & 127.300 & 292.700 & \\
\hline & & Zakat & 590.000 & 534.960 & 55.040 & \\
\hline & & Jumlah & 2.385 .000 & 1.727 .740 & 657.260 & 657.260 \\
\hline \multirow[t]{4}{*}{5.} & Juli & Tnfak & 570.000 & 32.500 & 537.500 & \\
\hline & & SAY & 390.000 & 278.000 & 712.000 & \\
\hline & & Zakat & 600.000 & & 600.000 & \\
\hline & & Jumlah & 1.560 .000 & 310.500 & 1.249 .500 & 1.249 .500 \\
\hline \multirow[t]{6}{*}{6.} & Agustus & Infak & 585.000 & 617.290 & 32.290 & \\
\hline & & SAY & 445.000 & 80.000 & 365.000 & \\
\hline & & Zakat & 340.000 & 291.650 & 48.350 & \\
\hline & & Jumlah & 1.370 .000 & 988.940 & 381.060 & \\
\hline & & & & & 32.290 & \\
\hline & & & & & 348.770 & 348.770 \\
\hline \multirow[t]{4}{*}{7.} & September & Tnfak & 190.000 & 243.250 & 53.250 & \\
\hline & & SAY & 180.000 & & 180.000 & \\
\hline & & Zakat & 727.500 & 870.350 & 142.850 & \\
\hline & & Jumlah & 1.097 .500 & 1.113 .600 & 16.100 & \\
\hline \multirow[t]{4}{*}{8.} & November & Infak & 737.500 & 452.750 & 284.750 & \\
\hline & & SAY & 325.000 & 80.000 & 245.000 & \\
\hline & & Zakat & 1.321 .500 & 1.543 .320 & 221.820 & \\
\hline & & Jumlah & 2.384 .000 & 2.076 .070 & 307.930 & 307.930 \\
\hline \multirow[t]{7}{*}{9.} & Desember & Infak & 895.000 & 7.455 .000 & 149.500 & \\
\hline & & SAY & 125.000 & 135.000 & 10.000 & \\
\hline & & Zakat & 1.150 .000 & 686.500 & 463.000 & \\
\hline & & Jumlah & 2.170 .000 & 1.567 .000 & 603.000 & \\
\hline & & & & & 10.000 & \\
\hline & & & & & 593.000 & 593.000 \\
\hline & & TOTAL & 17.352 .500 & 8.935 .670 & & $\begin{array}{l}8.390 .640 \\
\end{array}$ \\
\hline
\end{tabular}

Sebenarnya dari awal peneliti ingin menganalisis data dari awal berdiri sampai sekarang, akan tetapi karena data-data di tahun 2001-2003 tidak bisa di-

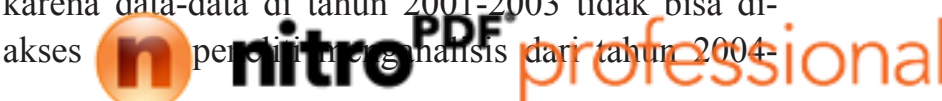


2007 yang hasilnya sebagai berikut. Berdasarkan data-data yang telah ada ternyata pemasukan dan pengeluaran mengalami instabilitasi, merujuk pada data diatas pemasukan di tahun 2004-2005 sebesar Rp 41.893.600,00; pemasukan ditahun 2005-2006 sebesar Rp 72.116.000,00; sedangkan pada tahun 2007 pemasukannya sebesar Rp 17.352.500,00; hal ini merupakan sesuatu yang wajar karena terkait dengan adanya dua faktor yaitu faktor internal dan faktor eksternal.

Faktor internal berasal dari orang-orang dalam itu sendiri, yaitu kurang maksimalnya dalam mengelola zakat di Lembaga Amil Zakat "Bina Umat Mandiri" Kabupaten Ngawi. Hal tersebut dapat disebabkan karena berbagai sebab seperti di antaranya adalah karena mengelola zakat hanya sebagai pekerjaan sampingan; tidak ada penghargaan yang tinggi terhadap jenis pekerjaan ini karena di anggap cukup dikerjakan seadanya, di waktu yang tersisa dan sederhana. Kemudian pekerjaan ini juga di kesampingkan setelah pekerjaan lain. Penyebab yang lain karena kurangnya disiplin; memang saat ini kebiasaan tidak disiplin sudah menjadi kebudayaan kita, sehingga sulit untuk dihilangkan. Akan tetapi meskipun sulit pasti bisa untuk mengubahnya ketika di lembaga ini mempunyai komitmen yang tinggi untuk meraih suatu hasil yang maksimal.

Sedangkan dari faktor eksternal yaitu terdapat pada sistemnya yang ada sekarang ini, yaitu sistem kapitalis. Ketika para individunya yang terdapat disebuah organisasi seperti di Lembaga Amil Zakat "Bina Umat Mandiri" sudah berusaha dengan sungguh-sungguh untuk mengentaskan kemiskinan masyarakat sedangkan sistem yang ada adalah sistem yang menuntut untuk mementingkan diri sendiri, maka adanya Lembaga Amil Zakat pun tidak akan mendapatkan hasil yang berarti.

Oleh sebab itulah peran negara dalam bentuk tanggung jawabnya mengenai kebutuhan rakyat sangatlah penting dan harus dilakukan secara menyeluruh bukan hanya secara parsial saja. Hal ini berbeda, ketika ada negara Islam yang pemimpinnya atau imamnya sangat bertanggung jawab. Contohnya ketika khalifah Umar bin Khattab yang harus memanggul sekarung bahan makanan kesalah satu keluarga miskin. Dalam kisah tersebut, bagaimana seorang khalifah dengan rela mengangkat sekarung bahan makanan dari gudang kerumah seorang ibu yang mengeluh bahwa khalifah tidak pernah memperhatikan mereka. Karena ketidakmampuan membeli makanan, ibu tersebut terpaksa memasak batu untuk menenangkan anaknya yang meminta makanan. Mendengar keluhan tersebut, Umar Bin Khattab yang saat itu tengah melakukan kunjungan kerakyatnya merasa bersalah. Sebagai tanggung jawabnya terhadap rakyatnya, khalifah Umar dengan rela mengangkat sendiri sekarung bahan makanan untuk diberikan kepada ibu tersebut, bahkan pengawalnya, tidak diijinkan ketika akan membantu. Beliau tahu, ia akan dimintai pertanggungjawaban oleh Allah SWT pada hari akhir nanti. Beliau bahkan pernah berkata, "Andaikan ada seekor keledai diwilayah Irak yang kakinya terperosok dijalan, aku takut Allah SWT akan meminta pertanggungjawabanku karena tidak memperbaiki jalan tersebut". Hewan yang terperosok saja sangat dikhawatirkan oleh khalifah, apalagi rakyat yang kelaparan.

Kisah tersebut membuktikan, bahwa pemimpin mempunyai tanggung jawab besar terhadap kebutuhan pokok masyarakat. Dalam syariat Islam, negaralah yang bertanggung jawab dalam memberikan jaminan pemenuhan kebutuhan primer kepada rakyat. Bahkan Rasulullah pernah mengatakan, "seseorang imam (pemimpin) bagaikan pengembala. Dia akan dimintai pertanggung jawaban atas gembalanya (rakyatnya)."

\section{KESIMPULAN DAN SARAN}

\section{Kesimpulan}

Kesimpulan dari penelitian ini antara lain:

Pertama, Lembaga Amil Zakat "Bina Umat Mandiri" Kabupaten Ngawi menerapkan sistem open management (manajemen keterbukaan). Artinya dalam pendapatan, pengelolaan, serta penyalurannya dapat diketahui oleh masyarakat umum melalui majalah tri wulan. Sehingga dengan menggunakan sistem ini masyarakat percaya dan mengetahui dengan jelas kemana arah zakat yang mereka keluarkan.

Kedua, dalam rangka pengentasan kemiskinan Lembaga AmilZakat"Bina Umat Mandiri" Kabupaten Ngawi melakukan berbagai upaya seperti penyaluran beeasiswa, kafalah du'at, waqaf al-Qur'an dan iqra', bantuan pendidikan TPA dan TKIT, bantuan renovasi masjid atau mushalla, bantuan daerah bencana, daurah pembinaan umat.

Ketiga, zakat yang ada di Lembaga Amil Zakat "Bina Umat Mandiri" Kabupaten Ngawi ini, dilihat dari hasilnya memang belum $100 \%$ mencapai target untuk mengentaskan kemiskinan, akan tetapi dari awal tahun berdirinya sudah mengalami peningkatan yang lebih baik. Kalau pada awalnya Lembaga Amil Zakat ini hanya aktif ketika pada bulan ramadhan saja, sekarang pada setiap bulannya sudah ada penerimaan 
dari masyarakat sekitar, yaitu melalui kerjasama dengan yayasan "Harum" Kabupaten Ngawi dan donatur rutin perbulan dari Instansi-instansi lain seperti lembaga pendidikan yang berada di Kabupaten Ngawi dan sekitarnya.

\section{Saran}

Dari hasil penelitian dan pembahasan yang penulis lakukan terhadap permasalahan yang terdapat pada Lembaga Amil Zakat "Bina Umat Mandiri" Kabupaten Ngawi, maka penulis mengajukan usulanusulan dan saran-saran, sebagai berikut:

Pertama, demi terwujudnya suatu Lembaga Amil Zakat yang profesional, amanah, terpercaya maka sudah selayaknyalah para pengurus Lembaga Amil Zakat "Bina Umat Mandiri" Kabupaten Ngawi untuk lebih mengoptimalkan kembali upaya-upaya pengentasan kemiskinan yang selama ini sudah berjalan sehingga benar-benar terwujud secara nyata dan bisa dirasakan oleh masyarakat umum.

Kedua, dalam rangka mewujudkan pengentasan kemiskinanyangadadiKabupatenNgawi,makaupayaupaya yang dilakukan seyogyanya lebih difokuskan lagi pada usaha-usaha yang besifat produktif, seperti penyaluran program beasiswa kepada orang-orang yang kurang mampu dalam mengenyam pendidikan, karena ini mampu untuk dijadikan investasi guna mendukung kondisi perekonomian masyarakat yang lebih baik sehingga kondisi kemiskinan ini pun mampu untuk dituntaskan.

Ketiga, berdasarkanatastuntutanprofesionalisme sudah seyogyanya pengelola zakat, yaitu para amil untuk mengelola secara fokus dan full time. Sehingga dapat dikatakan bahwa amil zakat adalah sebuah profesi, sebagaimana profesi-profesi yang lain, bukan hanya sebagai profesi sambilan. Peneliti berharap Lembaga Amil Zakat ini mampu menjadi titik terang awal penghapusan kesenjangan sosial, khususnya yang ada di Kabupaten Ngawi.

\section{DAFTAR RUJUKAN}

Al-Qur'an al-Karim .1996. Al-Qur'an Al-Karim dan Terjemahnya. Semarang : PT Karya TohaPutra.

Al Albani, Muhammad Nashiruddin. 2007. Shahih Sunan Abu Daud. Jakarta: Pustaka Azzam.

Al Albani, Muhammad Nashiruddin. 2007. Shahih Sunan Ibnu Majah. Jakarta : Pustaka Azzam.

Al Albani, Muhammad Nashiruddin. 2006. Shahih

Sunan An-Nasa'i. Jakarta : Pustaka Azzam.

Al-Syaikh, Yasin Ibrahim. 2004. Zakat Menyempurnakan Puasa Membersihkan Harta.
Bandung: Marja.

An-Nabhani, Taqyuddin. 1996. Membangun Sistem Ekonomi Alternatif Perspektif Islam. Surabaya:: Risalah Gusti.

Arikunto, Suharsimi. 2002. Prosedur Penelitian Suatu Pendekatan Praktek. Jakarta: Rineka Cipta.

Departemen Agama. 2005. Pedoman Penulisan Karya Ilmiah. Universitas Islam Negeri. Malang.

Departemen Agama RI. 2003. Petunjuk Pelaksanaan Pembinaan Lembaga Pengelolaan Zakat. Direktorat Jendral Bimbingan Masyarakat Islam danPenyelenggaraan Haji. Direktorat Pengembangan Zakat dan Wakaf.

Departemen Agama RI. 2003. Petunjuk Pelaksanaan Pengendalian dan Evaluasi Pengelolaan Zakat. Proyek Peningkatan Zakat dan Wakaf. Direktorat Jenderal Bimbingan Masyarakat Islam dan Penyelenggaraan Haji.

Drajat, Zakiyah. 1993. Zakat Pembersih Harta dan Jiwa. Jakarta : YPI RUHAMA.

Faisal, Sanapial. 1999. Format-format Penelitian Sosial. Jakarta: PT Grafindo Persada.

Hafidhuddin, Didin. 2007. Agar Harta Berkah dan Bertambah. Jakarta : Gema Insani Press.

Inayah, Gazi (2003) Teori Kompreherensip Tentang Zakat dan Pajak. Yogyakarta: Tiara Wacana.

Marzuki. 1997. Metodologi Rizet. Yogyakarta: BPFE-UI.

Moleong, Lexy. 2002. Metode Penelitian Kualitatif. Bandung: Remaja Rosdakarya.

Muhammad, Sahri. 2006. Mekanisme Zakat dan Permodalan Masyarakat Miskin. Malang: Bahtera Press.

Mulyana, Deddy. 2004. Metodologi Penelitian Kualitatif. Bandung: Remaja Rosdakarya.

Qardhawi, Yusuf. 1987. Hukum Zakat. Jakarta: Pustaka Litera Antar Nusa.

Qardhawi, Yusuf. 2005. Spektrum Zakat dalam Membangun Ekonomi Kerakyatan. Jakarta: Zikrul Hakim.

Ramulyo, Idris. 2004. Hukum Perkawinan, Hukum Kewarisan, Hukum Acara Peradilan Agama dan Zakat Menurut Hukum Islam. Jakarta: Sinar Grafika.

Sabiq, Sayid. 1977. Fiqih Sunnah. Beirut: Darul Fikri.

Sahhatih, Syauqi Ismail. 2007. Penerapan Zakat dalam Bisnis Modern. Bandung: Pustaka Setia.

Shaltut, Mahmud. 1966. Ala Fatawa. Kairo.

Sudirman, 2007. Zakat dalam Pusaran Arus Modernitas. Malang : UIN Press. 
34 Jurisdictie, Jurnal Hukum dan Syariah, Volume 1, Nomor 2, Desember 2010, hlm 01-92

Suyitno, Heri Junaidi,Adib Abdushomad. 2005.

Anatomi Fiqh Zakat. Yogyakarta:Pustaka

Pelajar.

Yunus, Mahmud. 1990. Kamus Arab-Indonesia.

Jakarta: Hidakarya Agung.

Ensiklopedi Hukum Islam. 2001. Jakarta: PT Ichtiar

Baru Van Hoeve.

Buletin Binuma (Edisi 4: Juli 2007).

Majalah Al-Waie (Edisi 78 : Februari 2007)

Majalah Suara Islam (Edisi 8: November 2006) 